\title{
Chyliza gavryushini sp.n. (Psilidae) and Cypselosoma tibialis sp.n. (Cypselosomatidae) - two new dipterous species from Vietnam
}

\author{
Cbyliza gavryusbini sp.n. (Psilidae) and Cypselosoma tibialis sp.n. \\ (Cypselosomatidae) - два новых вида двукрылых насекомых из \\ Вьетнама
}

\author{
A.I. Shatalkin \\ А.И. Шаталкин \\ Zoological Museum, Moscow State University, Bol'shaya Nikitskaja str. 6, Moscow 125009 Russia \\ Зоологический музей МГУ, ул. Большая Никитская 6, Москва 125009 Россия. \\ KEY WORDS: Psilidae, Cypselosomatidae, new species, dipterous fauna of Vietnam. \\ КЛЮЧЕВЫЕ СЛОВА: Psilidae, Cуpselosomatidae, систематика, новые виды, фауна двукрылых \\ насекомых Вьетнама.
}

ABSTRACT. The following 2 new species are described from Vietnam: Chyliza gavryushini sp.n. (Psilidae) and Cypselosoma tibialis sp.n. (Cypselosomatidae). Types of new species are deposited in collection of Zoological Museum of Moscow University (ZMUM)

РЕЗЮМЕ. Приведены описания Chyliza gavryushini sp.n. (Psilidae) and Cypselosoma tibialis sp.n. (Cypselosomatidae) из Вьетнама.

\section{Introduction}

The present work is part of an ongoing series of papers on the cyclorrhaphous fauna of Vietnam. Types of two new species from Vietnam are deposited in collection of Zoological Museum of Moscow University (ZMUM). In the text I used morphological terminology, abbreviations of wing veins and cells, and setae after J.F. McAlpine (1981).

Taxonomic part

Family Psilidae Genus Chyliza Fallén, 1820

Genus Chyliza Fallén, 1820 including 118 described species has a worldwide distribution. Chyliza is an uniform morphologically genus, based the following combination of mostly unique characters: head hemispherical (not triangular in profile, without projecting frons and receding face); face concave below antennae, forming an angle at fore margin of subcranial cavity; occiput slightly concave; gena low; katatergite enlarged, callus-like; the presence of well-developed postmetacoxal bridge; hind femur subapically with shallow, mi- crotrichose, oval ventral pit [Buck 2010, fig. 60.5]; anal cell shorter than basal medial cell.

Species of Chyliza is usually characterized by black palpi. New species described bellow is distinguished by the palpi entirely yellow.

\section{Chyliza gavryushini Shatalkin sp.n.}

MATERIAL. Holotype: $\sigma^{7}$, Vietnam, Lai Châu Province, Sa Pa env. $\left(22.3872^{\circ} \mathrm{N}, 103.7867^{\circ} \mathrm{E}\right), 1682 \mathrm{~m}, 23 . V .2014$, D. Gavryushin (ZMUM).

DESCRIPTION. Male. Head yellow. Ocellar triangle black. Frontal triangle black, yellowish anteriorly up to ocellar triangle; its height to hind ocelli about 3 times more than its base. Upper occiput below posterior orbits and vertex with three black spots bordering among themselves in basic two third. Face entirely yellow. Scape entirely dark brown; pedicel dark brown, yellow dorsally; postpedicel entirely yellow, about 1.3 times as long as its width. Arista brown, its thickened basal part yellow. Width of feathering of arista makes about a quarter of width (height) of a postpedicel. Frons broad, its height about 1.1 times as long as its width; frontal index (the ratio between height of the frons from its anterior margin to hind ocelli and from hind ocelli to vertex) equal to 3.2. Mouthparts brownish yellow; palpi leaf-like and entirely yellow.

Thorax black. Prosternum, propleuron, humeral calli, upper part of katepisternum, postsutural sides of mesonotum in the form of the arcuate stripes proceeding up to scutellum yellow; scutellum yellow with triangular black area basally, lower surface of scutellum entirely yellow. Legs entirely yellow. Spur on middle tibia golden yellow. Fore tibia with ventral comb of black spinules basally; length of comb clearly more than half of tibia length. Wings transparent with a 
contrast brown apical spot in anterior part, limited from behind a vein $\mathrm{M}_{1+2}$ and by a level of a vein $\mathrm{dm}-\mathrm{cu}$ on length of a wing; this wing spot narrower on anterior margin and makes hardly more quarters of length of a wing (hardly less than thirds of wing length for posterior margin of the spot). Veins brown, in the base of wing up to a level of veins $R_{s}$ yellow. $M_{1+2}$ slightly curving on level of mouth of $\mathrm{R}_{2+3}$ towards $\mathrm{R}_{4+5}$. Section of $\mathrm{M}_{1+2}$ between $r-m$ and $d m-c u$ about 2.2 times more than previous one and about 1.3 times less than ultimate one. Halteres whitish yellow.

Abdomen black with dark appressed hairs except for last tergites. Tergite II with erect yellowish hairs on each side.

Body length $5.3 \mathrm{~mm}$; wing length $5.0 \mathrm{~mm}$.

Female unknown.

DIAGNOSIS. Chyliza gavryushini sp.n. belongs to the species group characterized by yellow palpi. Five Oriental species was known in this group: Ch. amaranthi de Meijere, 1911 (Java), Ch. angustifrons Shatalkin, 1998 (India), Ch. oreophila Shatalkin, 1998 (China, Szechuen), Ch. prominens Shatalkin, 1998 (Malaysia, Pahang). Ch. oreophila characterized by the yellow coloration of body is unlikely to be confused with Chyliza gavryushini sp.n. Ch. amaranthi differs well from new species in having the more longer hairs of arista (its feathering is equal to width of postpedicel), by the presence of a pair of small oval black frontoorbital spots oriented at an angle with respect to eye, by the absence of postsutural lateral stripes and of apical brown wing spot. Chyliza gavryushini sp.n. is closely related to two remaining species, Ch. angustifrons and Ch. prominens. These last differ in having more wider feathering of arista being equal to half of width of postpedicel and a wing pattern. Wings are smoky brownish in anterior half along costa in $C h$. angustifrons and in apical half in Ch. prominens.

Chyliza gavryushini sp.n. can be included in our key [Shatalkin, 1998] for identification of the Euroasian species of Chyliza as follows:

1. Palpi entirely yellow .. 2

- Palpi black; in Ch. palpibasis Shatalkin, 1998 bicolor, black apically and yellow basally ............................... 5

2. Thorax mostly yellow as in Ch. vittata Meigen, 1826 Laterotergite yellow. Frons yellow with brown oval spot before ocellar triangle. Palaearctic China Chyliza oreophila Shatalkin, 1998

- Thorax including laterotergite black. Frons with different pattern

3. Width of feathering of arista equal to width of 3rd antennal segment. Frons yellow with a pair of fronto-orbital spots similar to those of Ch. cylindrica (Walker, 1852); ocellar triangle brownish. Java

Chyliza amaranthi de Meijere, 1911

- Width of feathering of arista equal to or less than half of width of postpedicel. Frons yellow without fronto-orbital spots but with black frontal triangle

4. Width of feathering of arista equal to half of width of postpedicel. Wings smoky brownish in apical half or in anterior half.
- Width of feathering of arista makes about a quarter of width of a postpedicel. Wings with a contrast brown apical spot in anterior part, limited from behind a vein $\mathrm{M}_{1+2}$.................. Chyliza gavryushini Shatalkin, 1998 4a. Wings uniformly brownish in anterior half. India ......... Chyliza angustifrons Shatalkin, 1998

- Wings smoky brownish in apical half. Malaysia ............ Chyliza prominens Shatalkin, 1998

ETYMOLOGY. The species is named after my colleague Mr. D.I. Gavryushin.

$$
\begin{gathered}
\text { Family Cypselosomatidae } \\
\text { Genus Cypselosoma Hendel, } 1913
\end{gathered}
$$

The genus Cypselosoma Hendel, 1913 has been described on the sole species Cypselosoma gephyrae from Taiwan (Formosa). Externally this species resembles species of Copromyza Fallén, 1810 and Hendel has placed it in the Cypselinae (Sphaeroceridae). Hennig [1941] has included this genus, along with Formicosepsis de Meijere, 1916 (treated in the Sepsidae) in the Tylidae (Micropezidae). Later Hennig [1948] has placed Cypselosoma in the family Clusiidae. At last, the new family Cypselosomatidae with two genera Cypselosoma and Formicosepsis has been established Hennig [1958]. D. McAlpine [1993] has established a new genus Clisa for two species, Cypselosoma australis (McAlpine, 1966) and Cypselosoma disneyi (McAlpine, 1978).

Being based on that Cypselosomatidae and Pseudopomyzidae are in sister relation, Griffiths [1972] has united them in a single family Cypselosomatidae. This opinion has been supported by other authors [Hackman, 1982; J. McAlpine, 1987]. D. McAlpine [1996] has not accepted Griffiths point of view, having noted, that similarity between Cypselosomatidae and Pseudopomyzidae is based on simplesiomorphies. The European authors [Krivosheina, 1978; Merz, 2004, see also McAlpine, Shatalkin, 1998] also are inclined to treat these groups as independent families. I have no own opinion on the given question and I consider Cypselosomatidae and Pseudopomyzidae as separate families.

\section{Cypselosoma tibialis sp.n.}

MATERIAL. Holotype: $\sigma^{7}$, Vietnam, Lai Châu Province, Hoáng Liên $\left(22.33788^{\circ} \mathrm{N}, 103.77922^{\circ} \mathrm{E}\right), 2068$ m, 1.V. 2013, T.V. Galinskaya (ZMUM). Paratype: $\sigma^{\top}$, same locality as holotype, 7.V. 2013, T.V.Galinskaya (ZMUM).

DESCRIPTION. Male. Head black. Frons slightly widened, about 1.3 times narrower from the front than from behind (on a level of hind ocelli) and about 1.2 times longer than its width on anterior margin; it blackish, matt with small yellow spot in anterior part between frontal suture and compound eye; fronto-orbital plate in place of insertion of fronto-orbital bristles shining. Ocellar triangle black matt, frontal triangle black shining. Occiput blackish, matt, with very narrow shining yellow border along eyes margin; this bor- 
der passes on gena reaching subcranial cavity. Face brownish with very narrow shining yellow border along peristoma. Gena with shining yellow spot between mouth margin and compound eye, this spot bordering on place of insertion of vibrissal bristle; a surface of a gena between considered yellow spot and mentioned above the yellow border going on posterior eye margin and passing to gena, dark brown, shining. Clypeus black, shining. Antennae yellowish brown; postpedicel widely blackish dorsally, about 0.9 times as long as its width. Arista brown, practically bare. Mouthparts yellowish brown; palpi entirely light yellow. 3 pairs of fronto-orbital bristles present: first pair proclinate; second pair proclinate and lateroclinate; third pair reclinate and lateroclinate; pairs of proclinate and inclinate interfrontal bristles in anterior part of frons present; ocellar bristle large; postverticals parallel. Vibrissal bristle well developed.

Thorax. Mesonotum, greyish black, matt with narrow yellow border along parapsidal suture; Postpronotum (humeral callus) black shining. Pleura black shining. Katepisternum on upper margin with shining yellow stripe; mediotergite black, matt; scutellum black, matt with yellow apical spot between apical bristles. Legs yellow. Fore tibia and tarsi blackish; middle femur with brownish dorsal apical spot, last three tarsomeres of middle legs brown. Hind femur with brown narrow apical ring; hind tibia brownish in its $1 / 5$ apical part; last three tarsomeres of hind legs brown. Fore femur apically with 3 antero-ventral thick and short bristles (these slightly more than thickness of tibia) and with 2 long and 1 short postero-ventral bristles (largest of them more than thickness of femur); middle femur with 4 antero-ventral short bristles; middle tibia with 2 rows of 4 strong dorsal bristles each, with 2 ventral bristles in apical half and with 2 apical ventral bristles; hind femur apically with 2 antero-ventral bristles. Wings transparent. Veins $\mathrm{R}_{4+5}$ and $\mathrm{M}_{1+2}$ slightly converging apically; section of $\mathrm{M}_{1+2}^{4+5}$ between $\mathrm{r}-\mathrm{m}$ and $\mathrm{dm}$-cu about 1.5 times less than previous one and about 2.5 times less than ultimate one; basal medial and discal medial cells confluent; distal section of vein $\mathrm{CuA}_{1}$ developed. Halteres yellowish with brownish knob. Postpronotum with two bristles, one of them small, about 3.1 times shorter than another in holotype (about 2.6 times shorter in paratypes); on 6 pairs of dorsocentral and acrostichal bristles present; scapular bristles absent.

Abdomen black matt with the insignificant shine well visible on each side; tergite VI narrowly yellow on posterior margin; tergite II in posterior part with short erect black bristles on each side. Large syntergosternite $7+8$ widely yellow on anterior margin with a pair of strong bristles which about 2 times shorter than metatarsus of hind legs; epandrium yellow with a pair of analogous bristles which about 1.3 times shorter than those on syntergosternite.

Body length 3.2 (3.6 - paratype) mm; wing length $2.9(3.5) \mathrm{mm}$.

Female unknown.
DIAGNOSIS. Cypselosoma tibialis sp.n. is the second species in genus Cypselosoma. It distinguishes from known Cypselosoma gephyrae by a peculiar color pattern of middle and hind tibiae. Middle tibia brownish at least on its dorsal surface in C. gephyrae; hind tibia in this species mainly dark brown excepting a narrow ring in its base and fore femur with comb of 6 and more black spines; small bristle on postpronotum about 2.0 times shorter than another one and yellow stripe along the posterior eye margin does not reach the subcranial cavity in $C$. gephyrae.

ETYMOLOGY. The name of new species alludes to the distinguishing characters of tibiae.

ACKNOWLEDGEMENTS. For material, the assistance and advises, valuable criticism and many interesting discussion I am deeply indebted to my colleagues $D r$. D.I. Gavryushin, A.L. Ozerov, A.V. Sviridov (ZMMU), and T.V.Galinskaya (Department of Entomology, Lomonosov Moscow State University, Russia)

The reported study was supported by RFBR, research project No.13-04-01638 a.

\section{References}

Fallén C. F. 1820. Specim. entomolog. novam Diptera disponendi methodum exhibens. Lund. $26 \mathrm{p}$.

Fallén C.F. 1820. Opomyzides Sveciae. Lundae. 12 p.

Griffiths G.C.D. 1972. The phylogenetic classification of Diptera Cyclorrhapha with special reference to the structure of the male postabdomen // Ser.Entomol. 8. The Hague. 340 p.

Hackman R., 1980. A check list ofthe Finnish Diptera. II. Cyclorrhapha // Notulae Entomologicae. Vol. 60. No.3. P. 117-162.

Hendel F.H. Sauter's Formosa-Ausbeute. Acalyptrate Musciden (Dipt.). II. // Supplementa Entomologica. Vol. 2. P. 77-112.

Hennig W. 1941. Formicosepsis de Meijere und Cypselosoma Hendel, zwei Gattungen der Tyliden. Nachtrag zur Revision der Tylidon (Dipt.) // Stettiner Entomologische Zeitung. Bd.102. S.129-131

Hennig W. 1948. Über einige verkannte Dipteren-Gattungen // Acta Zoologica Lilloana. T.6. S.169-170.

Hennig W. 1958. Die Familien der Diptera Schizophora und ihre phylogenetische Verwandtschaftsbeziehungen // Beiträge zur Entomologie. Bd.8. S.505-688.

Krivosheina N.P. 1979. [A new representative of the family Pseudopomyzidae from the Palaearctic Fauna and the taxonomic position of this family in the system of Diptera] // Entomologicheskoe Obosrenie. Vol.58. P.179-189 [in Russian].

McAlpine D.K. 1966. Description and biology of Australian species of Cypselosomatidae (Diptera), with a discussion of family relationships // Australian Journal of Zoology. Vol.14. P.637685.

McAlpine D.K. 1978. A new species of Cypselosomatidae from Lord Howe Island (Diptera, Micropezoidea) // Australian Entomological Magazine.Vol.5. P.61-64.

McAlpine D. K. 1993. A new genus of Australian cypselosomatid flies (Diptera: Nerioidea) // General and Applied Entomology. Vol.25. P.2-4.

McAlpine D.K., Shatalkin A.I. 1998: 3.8. Family Pseudopomyzidae // Papp L. \& Darvas B. (eds.). Contributions to a Manual of Palaearctic Diptera. Vol.3. Higher Brachycera. Budapest: Science Herald. P.155-163.

McAlpine J.F. 1981 Morphology and terminology. Adults // J.F. McAlpine, B.V. Peterson, G.E. Shewell H.J. Teskey, J.R. Vockeroth, D.M. Wood (coord.). Manual of Nearctic Diptera. Vol.1. Agriculture Canada Monograph. No.27. P.9-64. 
McAlpine J.F. 1987. Chapter 55. Cypselosomatidae // J.F. McAlpine, B.V. Peterson, G.E. Shewell, H.J. Teskey, J.R. Vockeroth, D.M. Wood. (coord.). Manual of Nearctic Diptera. Vol 2. Agriculture Canada Monograph. No.28. P.757-760.

Meijere J.C.H., de 1911. Studien über südostasiatische Dipteren VI. // Tijdschrift voor entomologie. Vol.54. P.258-432.

Meijere J.C.H., de 1916. Studien über südostasiatische Dipteren. XI. Zur Biologie einiger javanischen Dipteren nebst Beschrei- bung einiger neuen javanischen Arten // Tijdschrift voor entomologie. Vol.59. P.184-213.

Merz B. 2004. Pseudopomyzidae // T. Pape (ed.). Fauna Europaea: Diptera, Brachycera. Fauna Europaea version 1.1: http:// www.faunaeur.org.

Shatalkin A.I. 1998. Review of the Asian species of Chyliza Fallen (Diptera, Psilidae) // Russian Entomological Journal. Vol. 6 (for 1997). P. 89-111. 